\title{
The Effect of Organo-Mineral Fertilizer Applications on the Yield of Winter Wheat, Spring Barley, Forage Maize and Grass Cut for Silage
}

\author{
Grace H. Smith'1, Keith Chaney', Charles Murray', Minh Son Le ${ }^{2}$ \\ ${ }^{1}$ Harper Adams University, Newport, UK \\ ${ }^{2}$ United Utilities Group PLC, Lingley Mere Business Park, Warrington, UK \\ Email: gsmith@harper-adams.ac.uk
}

Received 22 January 2015; accepted 6 February 2015; published 11 February 2015

Copyright (C) 2015 by authors and Scientific Research Publishing Inc.

This work is licensed under the Creative Commons Attribution International License (CC BY).

http://creativecommons.org/licenses/by/4.0/

(c) (i) Open Access

\begin{abstract}
Biosolids were applied with urea to produce a granulated organo-mineral fertiliser (OMF) for application by farm fertiliser equipment to a range of agricultural crops. The recommended rates of nitrogen, phosphate and potash were calculated for the test crops using "The Fertiliser Manual", which assesses the nutrient requirement based on previous cropping, rainfall and soil index. The OMF produced similar crop yields compared to ammonium nitrate fertiliser when applied as a top-dressing to winter wheat, forage maize and grass cut for silage in the cropping years 2010 to 2014. In 2012 the grain yield of spring barley top-dressed with OMF was significantly lower than the conventional fertiliser treatment, due to dry conditions following application. For this reason it is recommended that OMF is incorporated into the seedbed for spring sown crops and The Safe Sludge Matrix guidelines followed. The experimental work presented shows that OMF can be used in sustainable crop production systems as a source of nitrogen and phosphorus for a range of agricultural crops.
\end{abstract}

\section{Keywords}

Biosolids, Organo-Mineral Fertiliser, Crop Yield, Winter Wheat, Spring Barley, Forage Maize, Grass Silage

\section{Introduction}

Biosolids is the term for sewage sludge that has been treated to reduce the level of pathogens. The production of

How to cite this paper: Smith, G.H., Chaney, K., Murray, C. and Le, M.S. (2015) The Effect of Organo-Mineral Fertilizer Applications on the Yield of Winter Wheat, Spring Barley, Forage Maize and Grass Cut for Silage. Journal of Environmental Protection, 6, 103-109. http://dx.doi.org/10.4236/jep.2015.62012 
biosolids is approximately 2 million tonnes per annum in the UK and 10 million tonnes per annum in the EU expressed on a dry solids basis. These levels are increasing due to population growth and also because more households are being connected to sewage systems in the EU. Current disposal methods include anaerobic digestion, incineration and application to land. In the UK the application of biosolids to agricultural land is seen as the "Best Practicable Environmental Option" in most circumstances [1]. Biosolids provide a valuable source of major plant nutrients-nitrogen $\mathrm{N}$, phosphorus $\mathrm{P}$, potassium $\mathrm{K}$ and sulphur $\mathrm{S}$ as well as smaller quantities of trace nutrients. In addition the organic matter applied can improve soil quality, such as soil structural stability, workability and soil water holding capacity [2].

The main concerns with adding biosolids to agricultural land have been the impact of pathogens on the food chain and heavy metals on the soil [3] [4]. The treatment of sewage sludge removes pathogens, such as E. coli and campylobacter. To ensure public safety, the Water Industry in the UK developed The Safe Sludge Matrix [5], to provide guidelines for the application of biosolids to crops grown for food. Historically sewage sludge often contained high levels of heavy metals, such as copper, zinc, lead and cadmium, derived from industrial processes. Current low discharge levels of these metals to water, results in much lower concentrations in biosolids and so the issue of heavy metal build-up in soils is much reduced. There are guidelines for concentrations of heavy metals in the soil which must not be exceeded [6].

The application of biosolids to agricultural crops, such as winter wheat and grass cut for silage, has given significant yield responses [7] [8]. However, the biosolids applied can be very variable in their nutrient content depending on the processes utilised at the water treatment plant and the original composition of the sewage which varies considerably across the UK. In addition the low nitrogen to phosphorus ratio of the biosolids makes it difficult to match the application of biosolids to crop nutrient requirement. When the biosolids are applied at rates to supply the nitrogen requirement of a particular crop, more phosphorus is applied than is removed by the harvested crop resulting in accumulation of phosphate in the soil. Repeated applications will raise the soil phosphate index, which increases the potential for environmental damage due to soil erosion. However, phosphate minerals are a finite world resource that is being depleted and so it is important to utilise the phosphate in human waste as part of sustainable crop production systems [9].

This research has developed an organo-mineral fertiliser (OMF) created by adding urea to treated biosolids for use on a range of agricultural crops. Previous research reported that initial experiments comparing OMF with ammonium nitrate fertilisers gave similar crop responses [10]. This paper presents the results of further research on the response of agricultural crops to OMF from 2011 to 2014.

\section{Materials and Methods}

\subsection{Field Site}

The crop experiments were carried out on a mixed farm in Broxton, Cheshire (Grid ref: SJ 4770054400) by the Crop and Environment Research Centre, Harper Adams University (HAU). The site consists of slowly permeable clay loam soil which is seasonally waterlogged and the annual rainfall is approximately $1250-1500 \mathrm{~mm}$. A detailed description of the site and experiment is given by [10]. The crop rotation at the Broxton site was selected to limit the effect of pests and diseases within the crop, whilst still growing crops that are appropriate for the geographic area.

\subsection{Experimental Design}

The experimental site consisted of a 5 ha silage grass field (perennial rye grass), with a centralised 1.6 ha arable block. This block was split into four blocks of 12 plots (48 plots in total), allowing for up to four different arable crops to be grown in one season (Figure 1). The grass plots consisted of three blocks of the 2 treatments; 6 plots measuring at total of $432 \mathrm{~m}^{2}$.

\subsection{Fertilizer Treatments}

The experimental design consisted of two fertiliser treatments applied as a topdressing;

- Conventional fertiliser (Ammonium Nitrate, Triple Super Phosphate (TSP) and Muriate of Potash (MOP) for all cereals and silage grass and a 19:40:0 NPK fertiliser for forage maize).

- OMF (Thermally dried biosolids, Urea and MOP). 


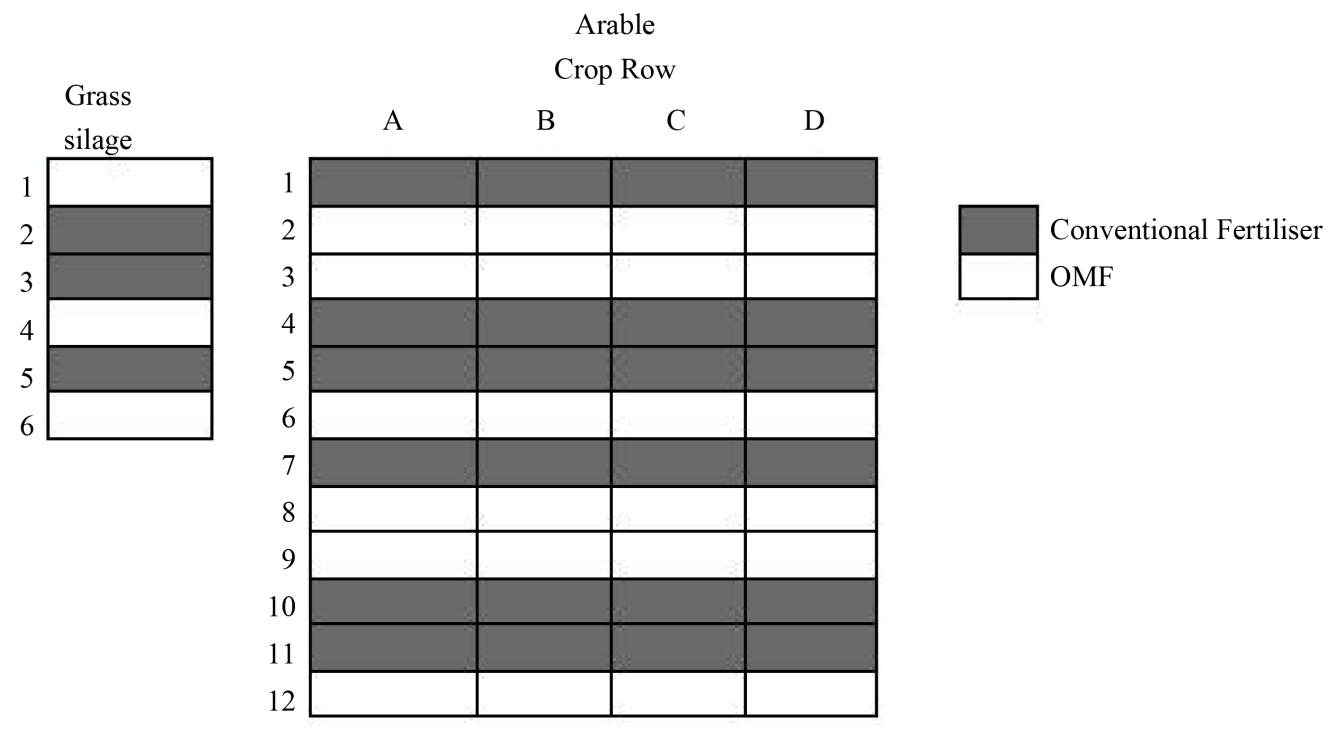

Figure 1. The experimental plot design of the Broxton arable and grassland site.

Ammonium nitrate was applied as the conventional treatment in 2010-2011 because soil analysis results indicated that there were sufficient phosphate and potash in the soil for crops to reach their potential yield. However, in the following three years ammonium nitrate, TSP and MOP were applied to provide the quantities of nutrients based on the recommendation obtained using The Fertiliser Manual [11]. In 2010/11 and 2011/12 a biosolid with NPK 3:4:0+ urea was applied to the plots and in 2012/2013 and 2013/2014 a 3:8:0 biosolid+ urea was used. Biosolids were applied to meet crop phosphate requirements with additional nitrogen and potassium applied to the biosolids plots as straight fertilisers to provide the crop requirement for each crop. The application rate and timing of fertilisers to the plots was conducted in accordance with recommendations given in The Fertiliser Manual recommendations. All the fertilisers were applied using a Kuhn $12 \mathrm{~m}$ pneumatic fertiliser spreader. Tramlines created between each plot were used to traffic the area to apply fertiliser to limit the effect of compaction on the crop. All treatment areas remained in the same location throughout the experiment.

\subsection{Crop Yield}

All arable crops were harvested using a Wintersteiger Nursery Master combine, the silage grass using a Haldrup grass harvester and the forage maize using a front mounted Champion 1200 forage harvester. The tramlines, running in an east to west direction, were harvested first, allowing the plots to be harvested in a north to south direction. Plot lengths were measured at the time of harvest, allowing for a yield per hectare to be calculated. Moisture content of the cereals and OSR were analysed using a Sinar moisture meter. Maize and grass silage were dried in an oven at $60^{\circ} \mathrm{C}$ for 24 hours to obtain their dry matter content.

\subsection{Statistical Analysis}

Statistical analysis was performed using Genstat $16^{\text {th }}$ edition. All data sets were analysed using One-way ANOVA to test for statistical significance at $95 \%$ confidence.

\section{Results}

\subsection{Winter Wheat}

The winter wheat grain yields for OMF and conventional fertiliser treatments of 7.0 and $7.3 \mathrm{t}$ for ha ${ }^{-1}$ respectively for the 2010-2011 cropping season and 6.12 and $6.59 \mathrm{t}^{-h} \mathrm{ha}^{-1}$ respectively for 2011-2012 were not significantly different (Table 1). The Thousand Grain Weight (TGW) and Specific Weight (SW), which are measures of the size of the grain, did not show significance in 2011-2012. The winter wheat grain yields obtained in this experiment were low $6.15 \mathrm{t} \cdot \mathrm{ha}^{-1}$ to average $7.70 \mathrm{t} \cdot \mathrm{ha}^{-1}$ for milling wheat in the UK [12], but typical of those ob- 
tained in mixed arable-grassland farming systems in western areas of the UK in 2010-2012.

\subsection{Spring Barley}

The spring barley grain yield of $4.5 \mathrm{t} \cdot \mathrm{ha}^{-1}$ for the conventional fertiliser treatment was significantly higher than that of $3.6 \mathrm{t}^{\mathrm{h}} \mathrm{h}^{-1}$ for the OMF treatment in 2012 (Table 1). The TGW of the conventional treatment being was also significantly higher than that of the OMF treatment. However, in the 2014 growing season, no significant grain yield differences were observed between the treatments, but the OMF treatment produced a significantly higher SW.

\subsection{Forage Maize}

The forage maize grown in 2010-2011 and 2012-2013 produced crop yields ranging from 11.3 to $11.97 \mathrm{t}^{-h^{-1}}$ (Table 1). Reference [12] gives typical fresh yields of $40 \mathrm{t}^{\mathrm{h}} \mathrm{h}^{-1}$ fresh weight for the United Kingdom, which equates to $12 \mathrm{t}^{-h^{-1}}$ dry matter at $30 \%$ moisture content. The dry matter content of the crop can vary depending on the weather conditions at harvest and was 46\% in 2010-2011 and 26\% in 2012-13. There were no significant differences between OMF and conventional fertiliser treatments for the dry matter yield, fresh yield or dry matter content of the crop in either year.

\subsection{Grass Silage}

The grass sward was sown in 2008 with a perennial ryegrass mixture and had been cut for silage in 2009 and

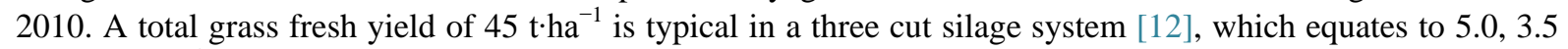
and $2.5 \mathrm{t}^{\mathrm{h}} \mathrm{ha}^{-1}$ of dry matter at first, second and third cut respectively (assuming grass silage at $25 \% \mathrm{DM}$ ). Although the grass yields in Table 2 show considerable variation around these yields at each of the silage cuts taken, the mean total grass yield for the three-year period was $11.33 \mathrm{t} \cdot \mathrm{ha}^{-1}$ for CF and $11.23 \mathrm{t} \cdot \mathrm{ha}^{-1}$ for OMF treatments (Figure 2). In each growing season the first cut of silage gave the highest yield and the third cut yield was the lowest, irrespective of treatment. There were no significant yield differences at the first or third silage cuts in 2011, 2012 or 2013, but at the second cut in 2011 the OMF treatment produced a significantly higher yield than the conventional fertiliser treatment. The mean yield for each cut over the three years indicates similar yields overall, between conventional fertiliser and OMF (Figure 2).

Table 1. The mean yields for winter wheat, spring barley and forage maize grown between 2010 and 2014 .

\begin{tabular}{|c|c|c|c|c|c|c|c|c|c|c|c|}
\hline Year & Crop & $\begin{array}{l}\text { Sowing } \\
\text { date }\end{array}$ & $\begin{array}{c}\text { 1st } \\
\text { application }\end{array}$ & $\begin{array}{c}\text { 2nd } \\
\text { application }\end{array}$ & $\begin{array}{c}\text { 3rd } \\
\text { application }\end{array}$ & $\begin{array}{c}\text { Harvest } \\
\text { date }\end{array}$ & Treatment & $\begin{array}{l}\text { Mean yield } \\
\text { (t/ha) }\end{array}$ & $\begin{array}{c}\text { Standard } \\
\text { error means }\end{array}$ & Significance & d.f. \\
\hline \multirow[t]{2}{*}{ 2010-2011 } & $\begin{array}{l}\text { Winter } \\
\text { wheat }\end{array}$ & 04.10 .10 & 06.04 .11 & 10.05 .11 & - & 03.09.11 & Conventional & 7.3 & 0.7714 & 0.427 & 11 \\
\hline & & & & & & & OMF & 7 & 0.3115 & & \\
\hline \multirow[t]{2}{*}{ 2011-2012 } & $\begin{array}{l}\text { Winter } \\
\text { wheat }\end{array}$ & 08.10.11 & 28.03.12 & 05.04 .12 & 24.05 .12 & 07.09.12 & Conventional & 6.12 & 0.258 & 0.114 & 23 \\
\hline & & & & & & & $\mathrm{OMF}$ & 6.59 & 0.317 & & \\
\hline \multirow[t]{2}{*}{ 2012-2013 } & $\begin{array}{l}\text { Spring } \\
\text { barley }\end{array}$ & 06.04 .13 & 24.04 .13 & 18.06.13 & - & 03.09 .13 & Conventional & 4.5 & 0.276 & 0.002 & 23 \\
\hline & & & & & & & $\mathrm{OMF}$ & 3.6 & 0.215 & & \\
\hline \multirow[t]{2}{*}{ 2013-2014 } & $\begin{array}{l}\text { Spring } \\
\text { barley }\end{array}$ & 01.04 .14 & 02.04 .14 & - & - & 04.09 .14 & Conventional & 2.98 & 0.197 & 0.13 & 11 \\
\hline & & & & & & & OMF & 2.67 & 0.235 & & \\
\hline \multirow[t]{2}{*}{2011} & $\begin{array}{l}\text { Forage } \\
\text { maize }\end{array}$ & 05.05 .11 & 05.05 .11 & 27.07.11 & - & 20.10 .11 & Conventional & 11.94 & 0.245 & 0.261 & 55 \\
\hline & & & & & & & OMF & 11.54 & 0.275 & & \\
\hline \multirow[t]{2}{*}{2013} & $\begin{array}{l}\text { Forage } \\
\text { maize }\end{array}$ & 23.05 .13 & 27.05 .13 & 23.06 .13 & - & 30.10 .13 & Conventional & 11.97 & 0.662 & 0.332 & 10 \\
\hline & & & & & & & $\mathrm{OMF}$ & 11.33 & 0.409 & & \\
\hline
\end{tabular}


Table 2. The mean grass dry matter yield of three cuts harvested in 2011, 2012 and 2013.

\begin{tabular}{|c|c|c|c|c|c|c|c|c|c|c|}
\hline Year & Crop & Treatment & Sowing data & $\begin{array}{c}\text { Cut } \\
\text { number }\end{array}$ & $\begin{array}{c}\text { Fertiliser } \\
\text { application date }\end{array}$ & $\begin{array}{l}\text { Harvest } \\
\text { date }\end{array}$ & $\begin{array}{l}\text { Mean dry } \\
\text { yield (t/ha) }\end{array}$ & S.E.M. & Significance & d.f. \\
\hline \multirow[t]{2}{*}{2011} & Silage grass & Conventional & 2008 & $1 \mathrm{st}$ & 06.04 .11 & 10.05 .11 & 4.7 & 0.199 & 0.729 & 5 \\
\hline & & OMF & & & & & 4.9 & 0.229 & & \\
\hline \multirow[t]{2}{*}{2011} & Silage grass & Conventional & 2008 & 2nd & 11.05 .11 & 13.07.11 & 3.1 & 0.193 & 0.025 & 5 \\
\hline & & OMF & & & & & 4.7 & 0.051 & & \\
\hline \multirow[t]{2}{*}{2011} & Silage grass & Conventional & 2008 & 3rd & 06.08.11 & 14.10 .11 & 0.1 & 0.016 & 0.255 & 5 \\
\hline & & & & & & & 0.1 & 0.005 & & \\
\hline \multirow[t]{2}{*}{2012} & Silage grass & Conventional & 2008 & 1 st & 28.03 .12 & 13.06.12 & 8.0 & 0.104 & 0.875 & 5 \\
\hline & & OMF & & & & & 8.2 & 0.707 & & \\
\hline \multirow[t]{2}{*}{2012} & Silage grass & Conventional & 2008 & 2nd & 05.07 .12 & 14.08.12 & 1.8 & 0.088 & 0.499 & 5 \\
\hline & & OMF & & & & & 2.0 & 0.282 & & \\
\hline \multirow[t]{2}{*}{2012} & Silage grass & Conventional & 2008 & 3rd & 30.08 .12 & 09.10.12 & 1.1 & 0.057 & 0.74 & 5 \\
\hline & & & & & & & 1.2 & 0.156 & & \\
\hline \multirow[t]{2}{*}{2013} & Silage grass & Conventional & 2008 & 1st & 25.04 .13 & 10.06 .13 & 8.1 & 0.552 & 0.181 & 5 \\
\hline & & OMF & & & & & 6.8 & 1.072 & & \\
\hline \multirow[t]{2}{*}{2013} & Silage grass & Conventional & 2008 & 2nd & 26.06 .13 & 01.08.13 & 5.1 & 0.297 & 0.147 & 5 \\
\hline & & OMF & & & & & 3.8 & 0.423 & & \\
\hline \multirow[t]{2}{*}{2013} & Silage grass & Conventional & 2008 & 3rd & 09.08.13 & 20.09 .13 & 2.0 & 0.034 & 0.998 & 5 \\
\hline & & & & & & & 2.0 & 0.195 & & \\
\hline
\end{tabular}

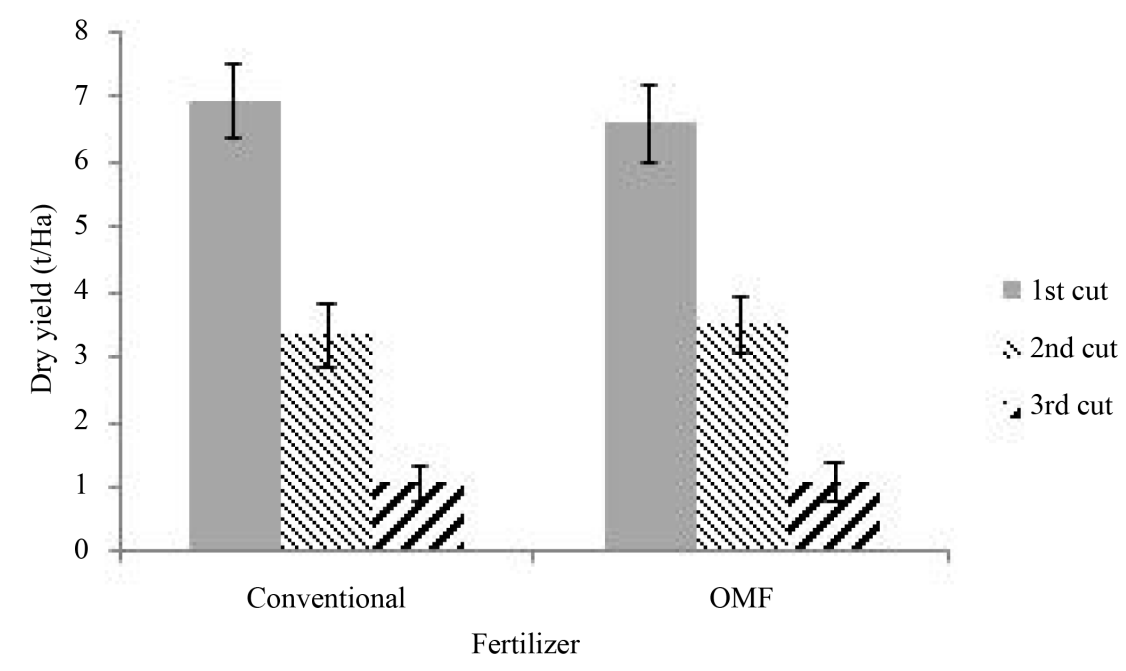

Figure 2. The mean dry yields for each cut over a three-year period.

\section{Discussion}

\subsection{Arable and Forage Crops}

The concept of this research was to develop a new fertiliser material based on the addition of urea to biosolids that could be used in sustainable crop production systems. The resultant mixture was dried and granulated to produce particles in the size range of 2 - $5 \mathrm{~mm}$ which were capable of being spread accurately with farm fertiliser application equipment. This would utilise the nitrogen and phosphorus from human waste as a valuable 
plant nutrient rather than continuing to utilise phosphate minerals which are a finite resource of our planet. The results presented are a continuation of the initial experiments reported by where OMF was applied to arable crops [10]. It is important to test new fertiliser materials over a number of cropping years and on a range of crops to ensure that they will perform in a wide variety of environmental conditions. OMF has been compared with ammonium nitrate as a nitrogen source on winter wheat, spring barley, forage maize and grass grown for silage in the cropping seasons 2010-11 to 2013-14.

Overall the results presented demonstrate that OMF gave comparable crop yields to ammonium nitrate fertiliser when applied as a top-dressing to winter wheat and forage maize.

This indicates that the organic nitrogen applied in the biosolids is released for uptake by the growing crop and in combination with the inorganic nitrogen applied as urea is sufficient to provide the requirements of the growing crop. It was also interesting to find that the grain size of the winter wheat measured by the weight of a thousand grains (TGW) or plumpness of the grain (SW) was not influenced by the addition of OMF. Grain size is an important quality indicator of winter wheat, especially for the variety Solstice which is a milling or bread making variety. Currently, the use of OMF for the production of bread making wheat is not be approved by milling organisations in the UK, but further data to support their potential as a suitable fertiliser would be needed prior to them being considered appropriate.

The NPK analysis of 3:4:0 or 3:8:0 make OMF particularly attractive for the basal dressing for forage maize as a replacement for mono ammonium phosphate (11:52:0) or diammonium phosphate (18:45:0) fertiliser. In these experiments OMF applied as a surface topdressing gave similar yields to the conventional fertiliser (19:40:0) fertiliser treatment. The application of OMF incorporated into the seedbed or preferably placed close to the seed would be a better option in commercial farming systems.

Spring barley was the one arable crop where the conventional fertiliser treatment produced a higher yield in 2012-2013 compared with that of the OMF. In 2013 there was no rain for the month following topdressing with the OMF making it very unlikely that the nutrients applied became available to the crop. In the more typical growing conditions experienced in 2013-14, with rainfall following application of the OMF, there was no significant difference in grain yield between the two fertiliser treatments. From these findings it is recommended that OMF should be incorporated into the seedbed for spring sown crops to ensure that the nutrients in the biosolids are in contact with moisture and become available to the growing crop.

\subsection{Grass Silage}

The three cut grass silage system produced its highest yield under both treatments at the first cut and the lowest at the third cut, as expected. Only one cut showed a significant difference, the second cut of 2010-2011, with OMF producing the higher grass matter yield (Table 2). This may be explained by the lack of $\mathrm{P}$ and $\mathrm{K}$ applied as the conventional treatment. Although the nutrients in the soil was deemed to be sufficient to support the growth of silage grass, that OMF contains both $\mathrm{P}$ and $\mathrm{K}$ and therefore the nutrients applied during this year were not balanced. The fertiliser applications to the plots in the following years, were balanced, and did not show significant differences.

\section{Conclusion}

The disposal of biosolids to land is considered the Best Environmentally Practical Option, but their potential to produce crops needs to be understood in order for them to be used effectively. The data presented here indicates that OMF can produce similar yields to conventional fertilisers, but their nutrient release may be influenced by environmental and meteorological factors. For this reason, it is recommended that OMF is incorporated into the seedbed of spring crops (such as spring barley or forage maize) to ensure that nutrient release is optimised. The effects of biosolids on crop quality need to be studied in order to assess what end markets OMF may be appropriate for and the products need to be applied in accordance with The Safe Sludge Matrix [5].

\section{Acknowledgements}

This research was funded by the European Union Seventh Framework Programme (FP7-ENV.2010.3.1.1-2 ENV) under grant agreement No. 265269. The authors would like to thank the farmers who allowed the experiments to be conducted on their land. 


\section{References}

[1] Taylor, M.J., Rollet, A.J., Martindale, T. and Chambers, B.J. (2011) Are We Underestimating Biosolids Crop Available Nitrogen Supply? Proceedings of the 16th European Biosolids and Organic Resources Conference, Leeds, 14-16 November, 1-9.

[2] Chambers, B.J., Withers, P.J.A. and Taylor, M.J. (2013) Biosolids Nutrient Management Matrix. Proceedings of the 18th European Biosolids \& Organic Resources Conference \& Exhibition, Manchester, 18-20 November 2013, 1-9.

[3] Gibbs, P.A., Chambers, B.J., Chaudri, A.M., McGrath, S.P., Carlton-Smith, C.H., Bacon, J.R., Campbell, C. and Aitken, M.N. (2006) Initial Results from a Long-Term, Multi-Site Field Study of the Effects on Soil Fertility and Microbial Activity of Sludge Cakes Containing Heavy metals. Soil Use and Management, 22, 11-21. http://dx.doi.org/10.1111/j.1475-2743.2006.00003.x

[4] Usman, K., Khan, S., Ghulam, S., Khan, M.U., Khan, N., Khan, M.A. and Khalil, S.K. (2012) Sewage Sludge: An Important Biological Resource for Sustainable Agriculture and Its Environmental Implications. American Journal of Plant Sciences, 3, 1708-1721. http://dx.doi.org/10.4236/ajps.2012.312209

[5] ADAS (2001) The Safe Sludge Matrix: Guidelines for the Application of Sewage Sludge to Agricultural Land. 3rd Edition, ADAS, Gleadthorpes.

[6] Department of the Environment (1996) Code of Practice for Agriculture Use of Sewage Sludge. DoE Publications.

[7] Cooper, J.L. (2005) The Effect of Biosolids on Cereals in Central New South Wales, Australia. 1. Crop Growth and Yield. Australian Journal of Experimental Agriculture, 45, 435-443. http://dx.doi.org/10.1071/EA03099

[8] Antille, D.L., Sakrabani, R. and Godwin, R.J. (2014) Effects of Biosolids-Derived Organomineral Fertilizers, Urea and Biosolids Granules on Crop and Soil Established with Ryegrass (Lolium perenne L.). Communications in Soil Science and Plant Analysis, 45, 1605-1621. http://dx.doi.org/10.1080/00103624.2013.875205

[9] Lane, G.P.F., Samuel, A.M. and Finch, H.J.S. (2014) Lockhart and Wiseman’s Crop Husbandry Including Grassland. 9th Edition, Woodhead Publishing, Cambridge.

[10] Deeks, L.K., Chaney, K., Murray, C., Sakrabani, R., Gedara, S., Le, M.S., Tyrrel, S., Pawlett, M., Read, R. and Smith, G.H. (2012) A New Sludge-Derived Organo-Mineral Fertilizer Gives Similar Crop Yields as Conventional Fertilizers. American Journal of Plant Sciences, 3, 1708-1721. http://dx.doi.org/10.4236/ajps.2012.312209

[11] DEFRA (2010) The Fertiliser Manual (RB209). 8th Edition, The Stationary Office, Norwich.

[12] Nix, J. (2014) Farm management Pocketbook. 45th Edition, Agro Business Consultants Ltd., Melton Mowbray. 
Scientific Research Publishing (SCIRP) is one of the largest Open Access journal publishers. It is currently publishing more than 200 open access, online, peer-reviewed journals covering a wide range of academic disciplines. SCIRP serves the worldwide academic communities and contributes to the progress and application of science with its publication.

Other selected journals from SCIRP are listed as below. Submit your manuscript to us via either submit@scirp.org or Online Submission Portal.
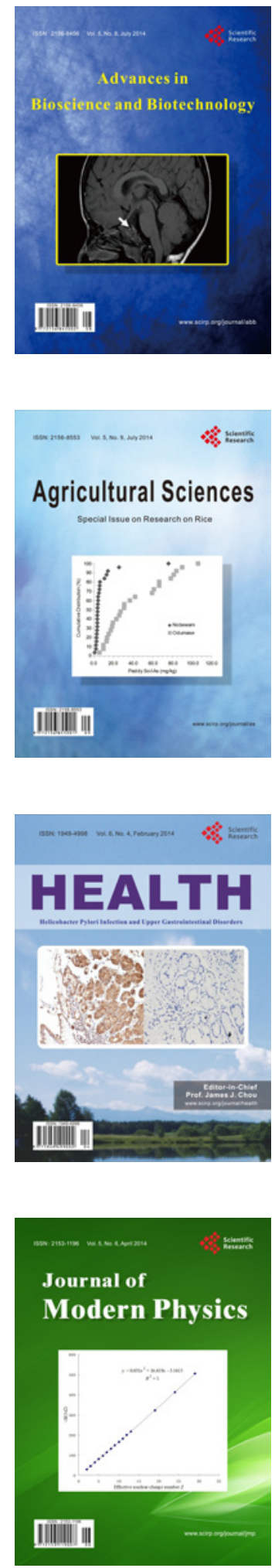
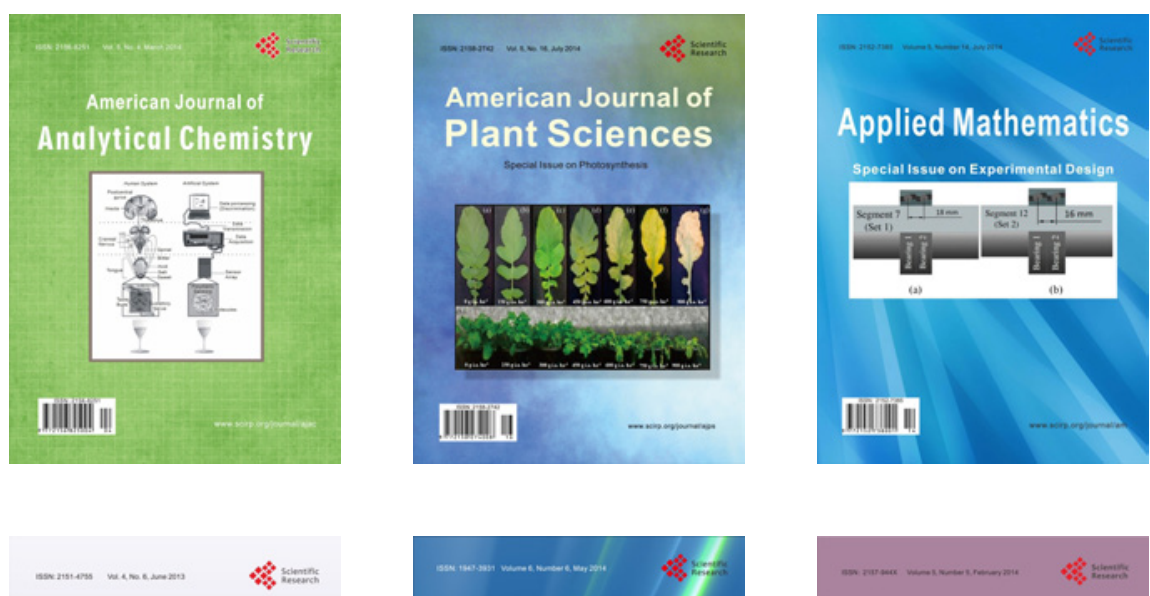

Creative Education
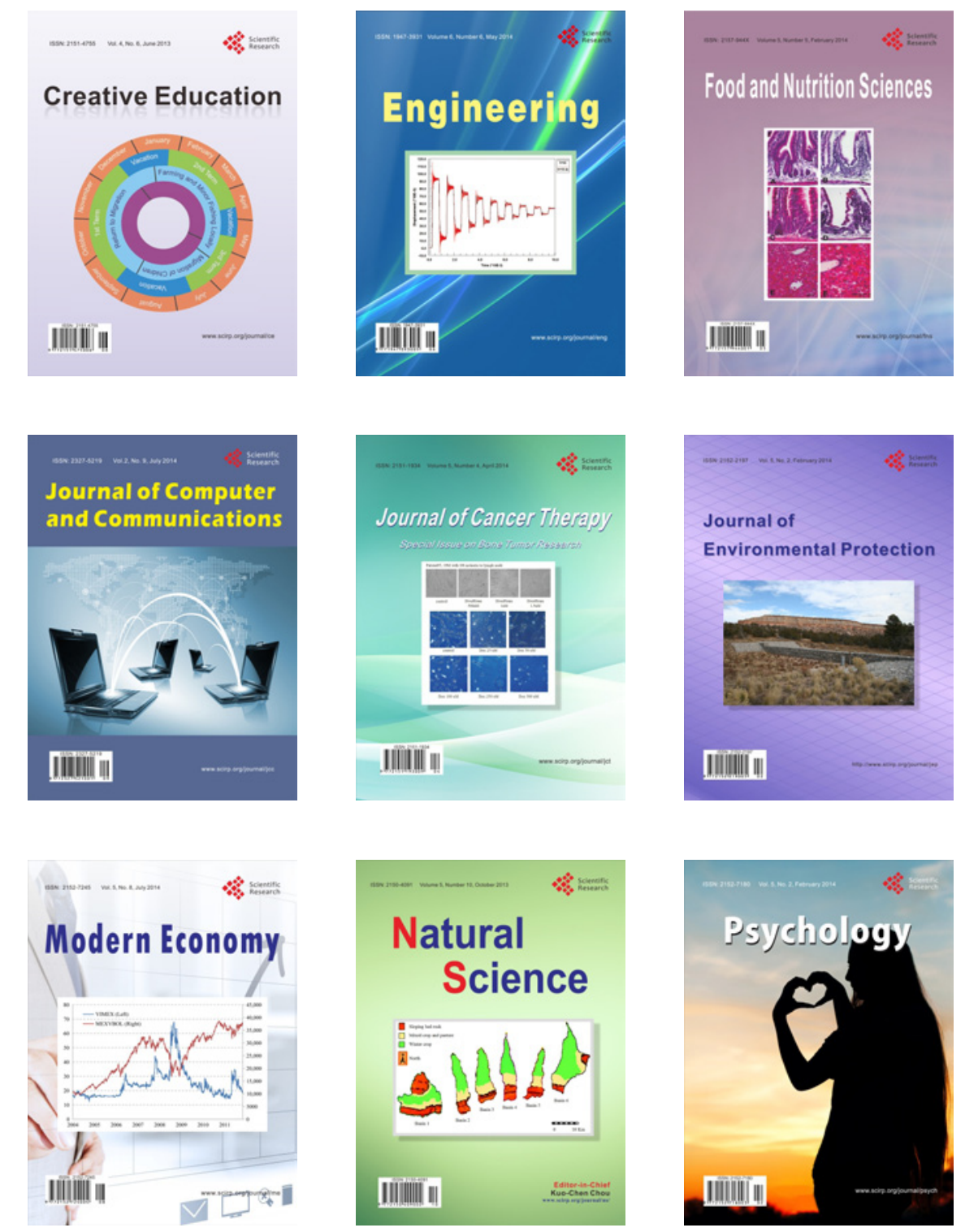